\title{
血行再建を行った大腿部発生軟部肉腫の検討
}

熊本大学医学部整形外科
西 田 公 明・米 村 憲 輔
加 藤 悌 二・薬師寺 俊 剛
高 木 克 公

\section{Vascular Reconstruction for Limb Salvage in Soft Tissue Sarcomas of Thigh}

\author{
Kimiaki Nishida, Kensuke Yonemura, Teiji Kato, \\ Toshitake Yakushiji and Katsumasa Takagi
}

Department of Orthopaedic Surgery, Kumamoto University School of Medicine, Kumamoto, Japan

\begin{abstract}
4 patients with soft tissue sarcoma of the thigh underwent wide resection of the tumor followed by vascular reconstruction. These patients were all female with ages ranging from 41 to 57 years (average, 51 years). The histological diagnosis of the tumors was as follows : 3 cases of liposarcoma and 1 case of malignant fibrous histiocytoma. Arterial reconstruction was performed with a saphenous vein in all patients and venous reconstruction in 3 cases. The duration of follow-up ranged from 10 to 28 months (mean 18 months). The revasculized vessels were found to be patent in all patients. MR angiography (MRA) was performed to evaluate the reconstructed vessels. Limitation of ROM around thigh and edema of the leg were observed postoperatively, while no local recurrence was seen. Vascular reconstruction for limb salvage in soft tissue sarcomas is preferable and MRA is useful for evaluating the reconstructed vessels.
\end{abstract}

Key words : Vascular reconstruction (血行再建), limb salvage（患肢温存), soft tissue sarcoma (軟部肉腫)

はじめに

軟部肉腫の手術において腫瘍が血管へ浸潤している 場合, 完全な切除縁を確保するために血行再建が必要 となる場合がある，今回我々は大腿部に発生した軟部 肉腫に対し, 血行再建を併用した患肢温存術を行い, その治療成績を中心に検討したので報告する.

\section{対象および方法}

症例は 4 例全て女性で, 年齢は平均 51 歳（41 から 57 歳), 診断は脂肪肉腫が 3 例, 悪性線維性組織球腫 （以下 MFH）1例であった. 術後経過観察期間は平 均 18 ケ月（10から 28 ケ月）であった.
手術方法は，生検部位を含め周囲の健常筋肉及び血 管を広範切除し, 全例大伏在静脈を用いて再建した。 3 例は動静脈を, 1 例は動脈のみを再建した. 再建血 管の長さは 12 から $22 \mathrm{~cm}$, 平均 $16 \mathrm{~cm}$ であった（表 1 ).

補助療法としては, MFH の 1 例のみ術後に化学療 法 (CYVADIC, CDDP) を行った.

以上の症例について, その治療成績を検討した.

\section{結果}

術中出血量は平均 $700 \mathrm{~g}$, 阻血時間は平均 58 分 $(20$ 分から 90 分）であった. 全例患肢の血行は良好であ り，2例に MR angiography（以下 MRA）を行い, 
表 1 血行再建症例

\begin{tabular}{c|c|c|c|c|c|c|c}
\hline \hline 症例 & 年齢 & 性別 & 診断 & 再建血管 & 再建血管長 & 機能評価 & 予後 \\
\hline 1 & 53 & 女 & MFH & 大腿動静脈 & $12 \mathrm{~cm}$ & $90 \%$ & DOD \\
2 & 41 & 女 & 脂肪肉腫 & 大腿動静脈 & $16 \mathrm{~cm}$ & $93 \%$ & NED \\
3 & 55 & 女 & 脂肪肉腫 & 大腿動静脈 & $12 \mathrm{~cm}$ & $93 \%$ & NED \\
4 & 57 & 女 & 脂肪肉腫 & 大腿動脈 & $22 \mathrm{~cm}$ & $80 \%$ & NED \\
\hline
\end{tabular}

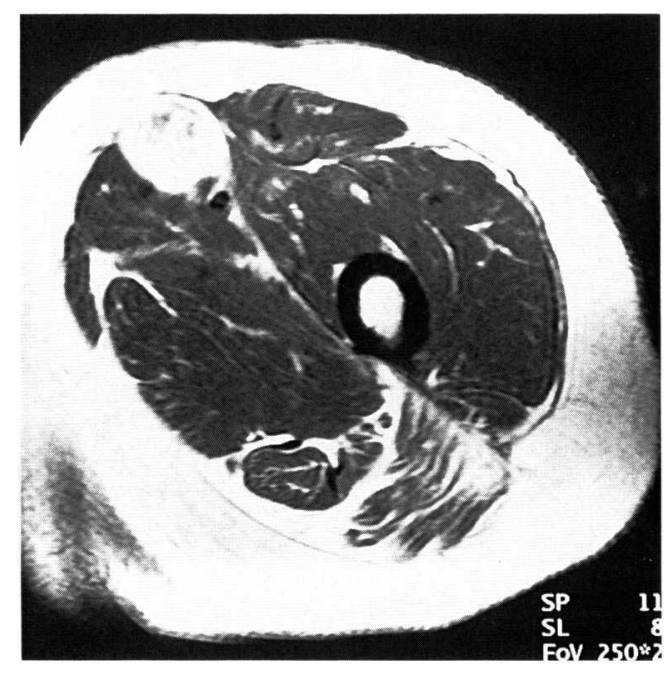

図 1 症例 3 ，左大腿脂肪肉腫再発例. MRI で は, 腫瘍は左大腿動静脈に接している.

再建血管が開存していることを確認した.

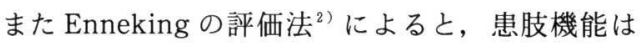
$80 \%$ 以上が温存されており, 機能的にも満足すべき結 果であった。

術後成績に関しては, 全例局所再発はみられなかっ た. 予後は MFH の 1 例が肺転移のため死亡したが, 他の 3 例は無病生存中である（表 1 ）.

合併症は全例に下肢の浮腫がみられたが, 患肢挙上, 圧迫包帯などで対処可能であった．また隣接関節の可 動域制限が 4 例中 3 例に生じた. しかし血管の急性閉 塞や感染などの重篤なものはなかった.

\section{症 例 供 覧}

症例 3,55 歳, 女性. 左大腿近位部の脂肪肉腫再 発例である. MRI では, 腫瘍は左大腿動静脈に接し ており, 合併切除が必要と判断した（図 1 ). 健側の 大伏在静脈を, 近位分岐部より膝関節部まで $35 \mathrm{~cm}$ 採取した. 腫瘍の近位, 遠位で動静脈を確保し, 腫瘍
を広範切除したのち動静脈を再建した. 切除標本では, 腫瘍により大腿静脈が圧排され扁平化しており, 安全 な切除縁での剥離は困難であり, 血管の温存は不可能 であった. 術後 10 ケ月で施行した MRA では, 吻合 部に軽度の狭窄像を認める屯のの, 血管の開存は良好 であった (図 2 ).

症例 4,57 歳, 女性. 脂肪肉腫の再発例である. MRI では, 右大腿動静脈を取り囲むように腫瘍が存 在した（困 3 ). 動静脈とともに腫瘍を広範切除し, 動脈のみを再建した．切除標本を検討すると，腫瘍が 大腿動静脈を完全に取り巻いていた. 術後 6 ケ月で施 行したMRAでは, 吻合部の狭窄像はなく血管の開 存は良好であった（図 4 ).

\section{考 察}

軟部肉腫の治療において, 腫瘍の大きさ, 腫瘍の局 在によっては, 安全な切除縁を確保するために血管の 温存が困難な場合がある.今回我々は患肢温存術の適 応を拡大し，血行再建を併用した手術を行った，血管 の温存が困難な軟部肉腫における血行再建の適応とし ては，側副血行が十分でないもの，動脈硬化が基礎に ないもの, 腫瘍切除後の患肢機能が良好と見込めるも のとしている.

再建材料に関しては Bergan ら ${ }^{1)}$, Yeager ら ${ }^{6)}$ は, 下腿では人工血管より大伏在静脈の開存率が高いが, 大腿においては両者に差がないと述べている. 人工血 管は手術時間が短縮され，切除した血管に応じて適切 なあのを使用でき，手術侵襲を縮小できるという利点 があるが，広範な組織の欠損を生じる腫瘍切除におい ては, 術後感染の危険性を考慮して, 当科では自家血 管を第一選択としている.

静脈の再建に関しては, 再建の必要性を強調する報 告 ${ }^{3)}$ が多いが, 術後の浮腫は静脈系のみでなく, リン パ系の関与も大きいとし, 必ずしも再建の必要性はな いとする報告 ${ }^{4)}$ ああり意見は一致していない. 今回の 検討でも症例 4 は動脈のみを再建してるが，この症例 


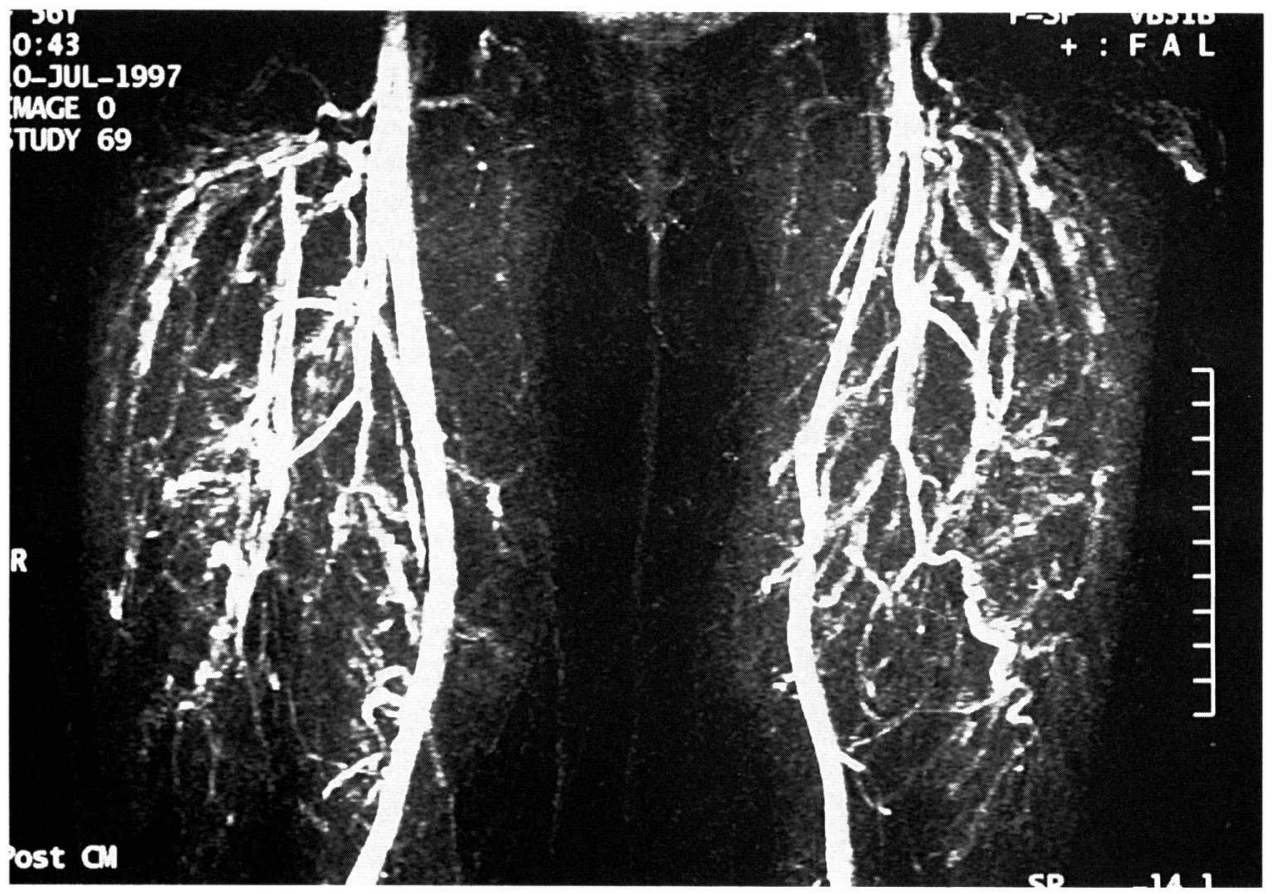

図 2 症例 3 。術後 10 ケ月で施行した MRA では，吻合部に軽度の狭窄像を認めるあのの血管の 開存は良好である。

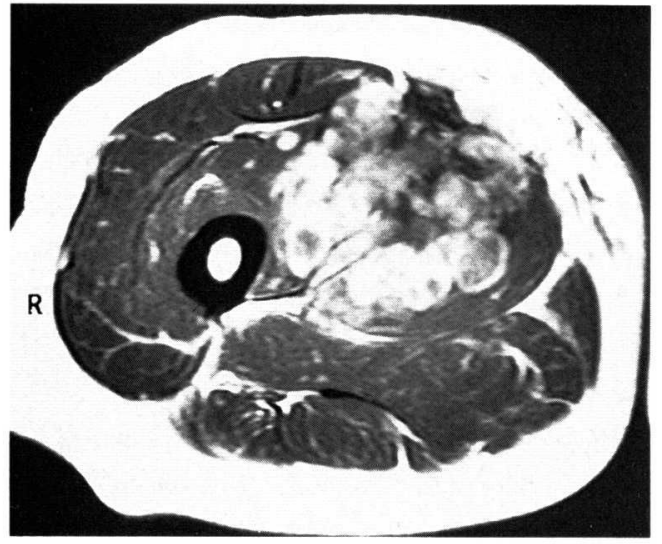

図 3 症例 4 ，右大腿脂肪肉腫の再発例。MRI では，右大腿動静脈を取り囲むように腫瘍 が存在した。

は再発例で経過が長く，術前の血管造影にて大腿静脈 が閉塞し，側副血行の存在が確認されたため静脈の再 建は行わなかった。

また再建血管の評価について Kawai ら ${ }^{5)}$ は，血管

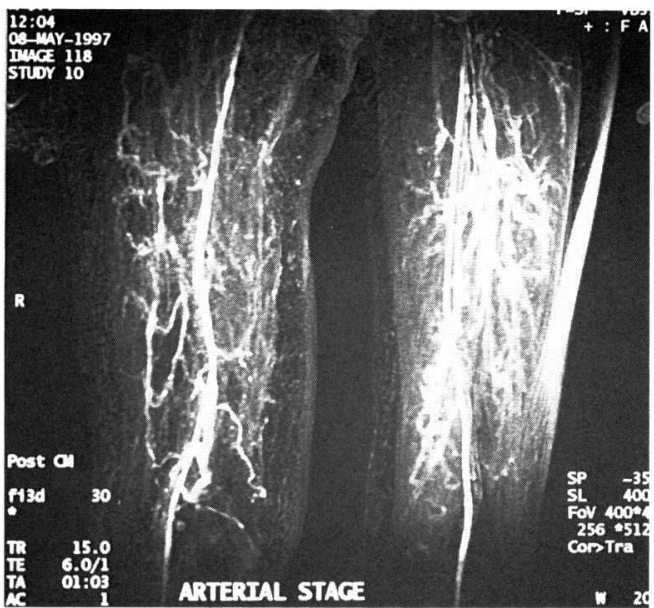

図 4 症例 4 ，術後 6 ケ月で施行した MRA では，吻 合部の狭窄像はなく血管の開存は良好である。

造影による評価を行っている．MRAを用いた評価に ついては現在までその報告はなく，今回呈示したよう にMRA は簡便で侵襲が少なく, 比較的有用と考元 
ている.

$$
\text { ま と め }
$$

1. 大腿部に発生した軟部肉腫 4 例に対し, 血行再 建を併用した患肢温存術を行った。

2. 全例再建血管の開存は良好であり，機能的にも 満足できる結果であった。

3. 再建血管の評価には MRA が有用であった.

\section{考文献}

1) Bergan, J. J. et al. : Randomization of autogenous vein and polytetrafluoroethylene grafts in femoraldistal reconstruction. Surgery, $92: 921-930,1982$.

2) Enneking, W. F. et al. : A system for the functional evaluation of reconstructive procedures after surgical treatment of tumors of the musculoskeletal system. Clin. Orthop., 286: 241-246, 1993.

3) Fortner, J. G. , Kim, D. K. and Shiu, M. H. : Limbpreserving vascular surgery for malignant tumors of the lower extremity. Arch. Surg., $140: 214-217,1980$.

4) Imparato, A. M. et al. : Major vascular reconstruction for limb salvage in patients with soft tissue and skeletal sarcomas of the extremities. Surg. Gynecol. Obstet., $147: 891-896,1978$.

5) Kawai, A. et al. : Vascular reconstruction in limb salvage operations for soft tissue tumors of the extremities. Clin. Orthop., 332 : 215-222, 1996.

6) Yeager, R. A. et al. : Differential patency and limb salvage for polytetrafluoroethylene and autogenous saphenous vein in severe lower extremity ischemia. Surgery, 91 : 99-103, 1982. 